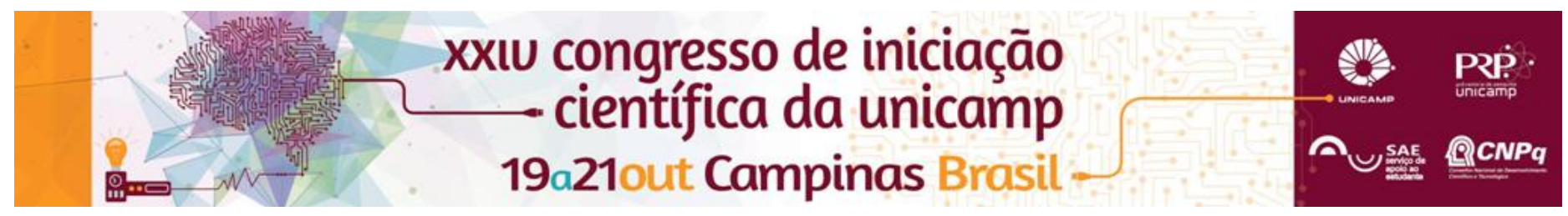

\title{
Estudo sobre os trabalho de Calder e Palatnik para proposições futuras em arte e tecnologia
}

\section{Lucas Antonio S. Perella (IC)}

\section{Resumo}

Esta pesquisa analisa os trabalhos e a vida dos artistas Alexander Calder e Abraham Palatnik, explorando os possíveis paralelos entre suas produções artísticas e a produção atual, compreendendo-os como importantes antecessores históricos, poéticos e técnicos dos da contemporaneidade. Além do viés teórico, a pesquisa teve um espaço de experimentações práticas executada por meio de recursos elétricos e eletrônicos geradores de uma exposição.

\section{Palavras-chave:}

Arte e tecnologia, Calder, Palatnik

\section{Introdução}

A arte cinética é uma das vertentes artísticas que explora o movimento, não como algo a ser representado, mas como parte integrante da obra. Com o desenvolvimento tecnológico e de novos materiais no início do século $X X$, experiências que visavam a integração real do movimento às obras de arte desencadeiam importantes peças que já integram a História da Arte. Enquanto o artista brasileiro Abraham Palatnik explora o movimento através de formas motorizadas, o norte americano Alexander Calder o explora por meio de seus móbiles, de modo mecânico e ambiental. O resultado final, nos dois casos, é surpreendente: as formas criadas pelos artistas parecem ter vida própria, uma espécie de espaço interno em cada elemento, que compõe um todo, harmonioso e singular.

\section{Resultados e Discussão}

O tempo passa a integrar a forma escultural de modo renovado, sendo um dos pontos mais importantes para a análise do trabalho dos artistas em questão. Calder vale se do peso e movimento próprio dos objetos e partículas do ar entorno das peças de metal que cria, para gerar o movimento desejado para seu trabalho. Palatnik faz uso da eletricidade para engendrar poesia ao rigor cientificista que toca seu universo de produção e pesquisas. Assim, nessa fusão que ele nos propõe, explora o movimento e o uso das cores em seus trabalhos, onde encontramos ritmo e suavidade no movimento de suas obras. Os dois artistas oferecerem boa oportunidade para compreendermos a expansão dos limites clássicos aplicados às linguagens artísticas da escultura e da pintura, inovando-as, atualizando-as a partir do elemento cinético. Durante a pesquisa, essas questões tiveram importância para a forma de pensar a escultura e sua relação com o movimento, e de como ela pode ser analisada.

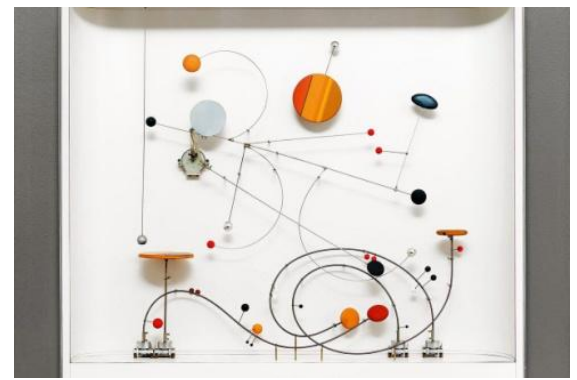

Figura 2. Objeto cinético, Abraham Palatnik, 1966.

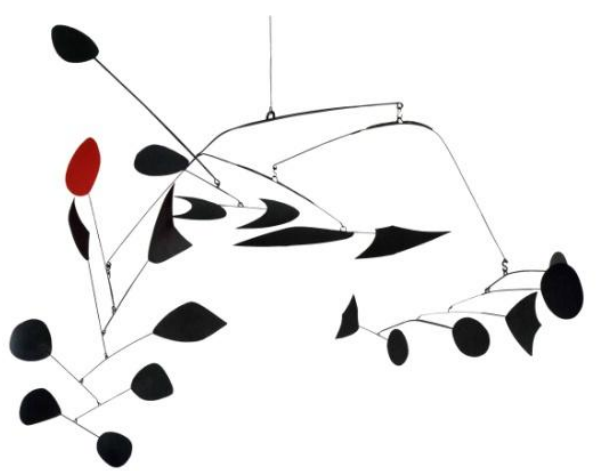

Figura 2. Red Triumphant (Vermelho Triunfante), Alexander Calder, 1963.

\section{Conclusão}

As formas de Calder sustentam um leve humor, e podem ser vistas indiretamente como caricaturas da natureza, com um encanto próprio, e que não buscam reproduzir o movimento, mas sim captá-lo. Já as formas motorizadas de Palatnik exploram os efeitos do espaçotempo sobre a nossa sensibilidade, com a projeção de imagens cromáticas que buscam, também, um ritmo, transformando-se em um meio de expressão plástica, graças às suas qualidades. Foi observada a influência de Calder para a ruptura estética que surgiu no trabalho de Palatnik, sobretudo após a exposição de seus móbiles na Galeria IBEU, em 1948, no Rio de Janeiro, numa de suas muitas passagens pelo Brasil. Com essa evidência, pude concluir que o artista norte americano teve uma grande influência para o desenvolvimento da arte cinética no Brasil, e para o uso de formas abstratas cinéticas na escultura.

\section{Agradecimentos}

A minha orientadora Prof ${ }^{a}$. Dr ${ }^{\mathrm{a}}$ Sylvia Furegatti, pela atenção e paciência, ao Prof. Tuneu, Roberto Freitas, a Fernanda Gândara, pelo seu apoio produtivo, e a minha família e amigos, por todo apoio e incentivo.

KRAUSS, Rosalind E. Caminhos da escultura moderna. 2. Ed. São Paulo, SP: Martins Fontes, 2007.

OSÓRIO, Luiz Camilo. Abraham Palatnik . São Paulo: Cosac Naify, 2004.

SARAIVA, Roberta (org.). C alder no Brasil: crônica de uma amizade. São Paulo, SP: Cosac Naify, 2006.

SWEENEY, James Johnson. A lexander Calder. New York, NY: Museu de Arte Moderna de Nova York, c1943. 